\title{
Challenges in the Healthcare Systems of Pakistan
}

\author{
Noureen* \\ Master degrees in Public Health and Political Science, Quiad-e-Azam University, Pakistan
}

Submission: February 17, 2017; Published: February 21, 2017

*Corresponding author: Noureen, Master degrees in Public Health and Political Science, Quaid-e-Azam University, Islamabad, Pakistan,

Email: alshifanoor@yahoo.in

Abbreviations: BHU: Basic Health Unit; CDC: Communicable Disease Control; LHV: Lady Health Visitor; RTI: Reproductive Tract Infection;

STI: Sexually Transmitted Infection; LHW: Lady Heath Worker

\section{Mini Review}

In a complex today's world, it is difficult to define exactly a health system. WHO defines it to include personal and public health services through inter-sectoral initiatives that primary action is to make better health [1]. The health enhancing interventions like road safety and pollution free environment are also part of system with traditional public health activities of health promotion. A country needs health system that protects all citizens against health and financial risks of illness. The individual physical dignity and integrity is recognized in international law. Health systems need to ensure that people must treated with respect accordingly with human rights. It's not the matter about financial expenditure made by governments to health systems but the strategies and procedures for health system effectiveness.

The health care delivery in Pakistan comprised three tiers of primary, secondary and tertiary. Pakistan has 1,142 hospitals, 5,499 dispensaries, 5,438 basic health units and 671 maternity and child health centers [2]. A basic health unit (BHU) is an extensive outreach system comprised of lady health visitor (LHV), mid-wives and communicable disease control (CDC). BHUs provide preventive services of EPI immunization, family planning (FP), skilled birth attendants in delivery, antenatal and post-natal care, nutritional counseling management of reproductive tract infection and sexually transmitted infection (RTI \& STI). A lady heath worker (LHW) refers patients to BHU, while if needed it refers patients to the next higher level of (RHC). Although, health systems usually don not have a defined boundary but low income countries have a long developmental process for strengthening of health systems.

Pakistan is a part of "Health for all by 2000". It is showing commitment by formulating and implementing health policies to achieve the target. However, alarmingly the neonatal mortality rate has increased past 20 years in Pakistan. Moreover, inequities between rural and urban population depict a sharp deviation in spite of commitments to health system. Despite all efforts in health sectors IMR is at 65 per live births while fertility rate is also stagnant at 3.9. After 18thamendment, the heath structure devolved that gave an opportunity to all provinces to improve health system to grass root level [3]. Pakistan witnessed growth of $10 \%$ per annum with a number of health program including TB, AIDs, Malaria and Food and Nutrition programs are implemented. Moreover, almost 6 million children have been immunized.

Pakistan is lacking in basic amenities and equipment that are necessary for running preventive and curative activities [4]. Therefore, regular assessment is needed to evaluate the weakness of health systems. The essential medicines provision according to the Alma-Ata Declaration's eight components is also neglected badly in Pakistan. Hence, current situation identifies the urgency for interventions are needed. Some better modified standards with institutional, political and social input is needed to achieve pace in healthcare.

Pakistan still spends only $2.6 \%$ of its national GDP towards healthcare while neighboring India spends $4.2 \%$. Additionally, there is a wide gap between rural and urban population which worsen the problem. Astaggering $38.8 \%$ of the population lives in rural areas with limited access to hospitals. Consequently, rural population mostly relies on alternative methods of treatment. In contrast, urban population has numerous private clinics and hospitals that is profitability better for investors.

The low penetration of health insurance market shows great need for an effective payment mechanism. Pakistan 
faces growing need to fix basic health concerns in the areas of tuberculosis, bacterial diarrhea, dengue fever, malaria, hepatitis, HIV and typhoid. Sadly, a very small percentage of the population has access to clean water which further exacerbates the diseases. Skilled medical graduates are continuing to grow but fail to attract in rural areas because of financial reasons. A sizeable percentage of these graduates go abroad to pursue higher studies and better employment. There is no concept of generic low-cost drugs in population. Pakistan lags far behind the developed nations with adequate nutrition, clean drinking water and better access to healthcare that are being long-standing challenges. Majority of Out of Pocket health expenditures create severe financial loss and the households bearing the catastrophic payments. The vicious cycle of poverty is hampering the economic growth.

\section{References}

1. WHO (2000) The world health report 2000: health systems: improving performance. World Health Organization, Geneva, Switzerland.

2. Pakistan economic survey (2015) Health and Nutrition.

3. Nishtar S, Boerma T, Amjad S, Alam AY, Khalid F, et al. (2013) Pakistan's health system: performance and prospectsafter the 18th Constitutional Amendments. Lancet 381(9884): 3193-3206.

4. Van Lerberghe W (2008) The world health report 2008: primary health care: now more than ever. World Health Organization, Geneva, Switzerland.

\section{Your next submission with Juniper Publishers} will reach you the below assets

- Quality Editorial service

- Swift Peer Review

- Reprints availability

- E-prints Service

- Manuscript Podcast for convenient understanding

- Global attainment for your research

- Manuscript accessibility in different formats ( Pdf, E-pub, Full Text, Audio)

- Unceasing customer service

Track the below URL for one-step submission https://juniperpublishers.com/online-submission.php 